\title{
5
}

\section{Human Pathogenic Viruses in the Marine Environment}

\author{
Albert Bosch, F. Xavier Abad, and Rosa M. Pintó
}

\subsection{INTRODUCTION}

Indigenous marine virus strains outnumber any form of life in the sea, usually occurring in billion amounts per liter (Danovaro et al., 2001; Fuhrman, 1999). However, although transspecific propagation of viruses may take place, the virus-host relationship tends to be quite constrained, and consequently human viruses are the only viral agents of public health concern in the marine environment.

Pathogenic viruses are routinely introduced into marine and estuarine waters through the discharge of treated and untreated sewage, since current water treatment practices are unable to provide virus-free wastewater effluents (Rao \& Melnick, 1986). It is estimated that the number of cases of gastrointestinal illness annually reported worldwide accounts for billions (Oh et al., 2003; Parashar et al., 1998). A good deal of these diarrheal cases are to some extent the result of the fecal contamination of the marine environment (Cabelli et al., 1982; Fattal \& Shuval, 1989; Koopman et al., 1982; Moore et al., 1994), while enterically transmitted hepatitis outbreaks, i.e. hepatitis A and E, have been reported to be associated to water and shellfish (Bosch et al., 1991, 2001; Halliday et al., 1991; Melnick, 1957; Reid \& Robinson, 1987).

The maintenance and assessment of the virological quality and safety of marine water systems employed for recreating and seafood harvesting is of seminal importance in the prevention of diseases transmitted through the fecal-oral route, and may lead to significant reductions of economic losses due to the closures of tourists resorts and shellfish harvesting areas. For this purpose, it is imperative to trace and characterize the type and origin of fecal contaminants in order to assess the associated health threat and the required corrective measures.

\subsection{VIRUSES AND DISEASES}

Present in sewage contaminated waters are well over 100 virus species able to cause a wide spectrum of illnesses in mankind including hepatitis, gastroenteritis, meningitis, fever,

Albert Bosch, F. Xavier Abad, and Rosa M. Pintó • Enteric Virus Laboratory, Department of Microbiology, University of Barcelona, Barcelona, Spain. 
Table 5.1. Human enteric viruses with potential waterborne transmission.

\begin{tabular}{lll}
\hline Genus & Popular name & Diseases caused \\
\hline Enterovirus & Polio & Paralysis, meningitis, fever \\
& Coxsackie A, B & $\begin{array}{c}\text { Herpangina, meningitis, fever, respiratory disease, } \\
\text { hand-foot-and-mouth disease, myocarditis, heart anomalies, } \\
\end{array}$ \\
& Echo & rush, pleurodynia, diabetes? \\
Hepatovirus & Hepatitis A & Meningitis, fever, respiratory disease, rush, gastroenteritis \\
Reovirus & Human reovirus & Hepatitis \\
Rotavirus & Human rotavirus & Gnknown \\
Mastadenovirus & Human adenovirus & Gastroenteritis, respiratory disease, conjunctivitis \\
Norovirus & Norwalk-like virus & Gastroenteritis \\
Sappovirus & Sapporo-like virus & Gastroenteritis \\
To be determined & Hepatitis E & Hepatitis \\
Mamastrovirus & Human astrovirus & Gastroenteritis \\
Parvovirus & Human parvovirus & Gastroenteritis \\
Coronavirus & Human coronavirus & Gastroenteritis, respiratory disease \\
Torovirus & Human torovirus & Gastroenteritis \\
\hline
\end{tabular}

rash, conjunctivitis, and may be diabetes or SARS (Table 5.1). However, few examples exist with epidemiological proof of waterborne transmission (Craun et al., 2002).

In 1979, it was estimated that between 5 and 18 million people die every year from gastroenteritis, rotavirus being the most important viral agent transmitted through the fecaloral route. In the developing countries the burden of rotavirus disease in children under 5 years of age has been estimated to be over 125 million cases annually, of which 18 million are severe cases, and 500,000-800,000 deaths in children under the age of 4 are attributable to rotavirus diarrhea (Oh et al., 2003; Parashar et al., 1998). In the developed world, mortality due to rotavirus infection is very low; however, it remains an important cause of morbidity and of hospitalization in young children. Additionally, hepatitis A accounts for around half the total number of hepatitis cases diagnosed worldwide, and some regions, such as some areas in the Mediterranean region, are still endemic for hepatitis A. Poliomyelitis, not too long ago the most feared viral disease, has not yet been eradicated, although this long pursued objective seems presently within reach. Norwalk-like viruses, the type species of genus Norovirus and formerly included in the SRSV (small round structured viruses), account for over $90 \%$ of foodborne gastroenteritis affecting children and adults (Lopman et al., 2003). Additionally, astroviruses were reported in 1996 to be second only to rotaviruses as a cause of hospitalization for childhood viral gastroenteritis (Glass et al., 1996), while adenoviruses and Sapporo-like viruses have also been recognized as significant etiological agents of epidemic nonbacterial diarrhea (Lopman et al., 2003). Hepatitis E virus, currently unclassified, is the primary cause in tropical and subtropical developing countries of an enterically transmitted non-A non-B hepatitis, with a mortality rate of up to $20 \%$ in pregnant women (Reyes, 1993; Schlauder \& Mushahwar, 2001).

In November 2002, the initial cases of the emerging disease denominated "severe acute respiratory syndrome" or SARS were reported (Ksiazek et al., 2003). Although the primary mode of transmission of the SARS coronavirus appears to be direct mucous membrane contact with infectious respiratory droplets and/or through exposure to fomites, at the time of writing 


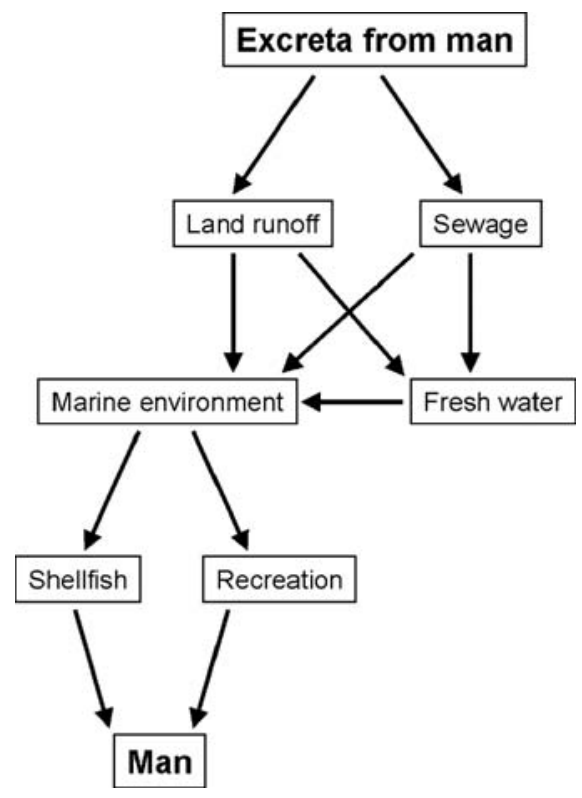

Figure 5.1. Routes of transmission of enteric viruses to become contaminants of the marine environment.

this chapter the role of fecal-oral transmission is unknown. In spite that several coronaviruses are spread by this route, there is no current evidence that this mode of transmission plays a key role in the transmission of SARS, although there is a considerable shedding of the virus in stool, where it remains stable at room temperature for several days (Tsang, 2003).

\subsection{THE FATE OF ENTERIC VIRUSES IN THE MARINE ENVIRONMENT}

The demands exerted by the expanding world population and industry make the marine environment increasingly susceptible to pollution from municipal sewage, industrial effluents, and agricultural wastes. Figure 5.1 illustrates the potential routes of transmission of enteric viruses to become contaminants of the marine environment. Seawater pollution control relies on secondary treatment of sewage and on the theoretically infinite dilution of wastes in the receiving waters. However, the marine environment, including oceans, has a finite ability to receive and recover from waste disposal practices, and certainly is incapable of unlimited waste assimilation.

Viruses are shed in extremely high numbers in the feces of infected individuals: e.g., patients suffering from gastroenteritis or hepatitis may excrete from $10^{5}$ to $10^{11}$ virus particles per gram of stool (Farthing, 1989). Viruses are present in high numbers in raw wastewater and current water treatment practices fail to ensure the complete removal of viral pathogens (Rao \& Melnick, 1986 ); consequently, viruses become environmental pollutants. There are several routes by which viruses reach the sea, including direct discharge of treated or untreated 


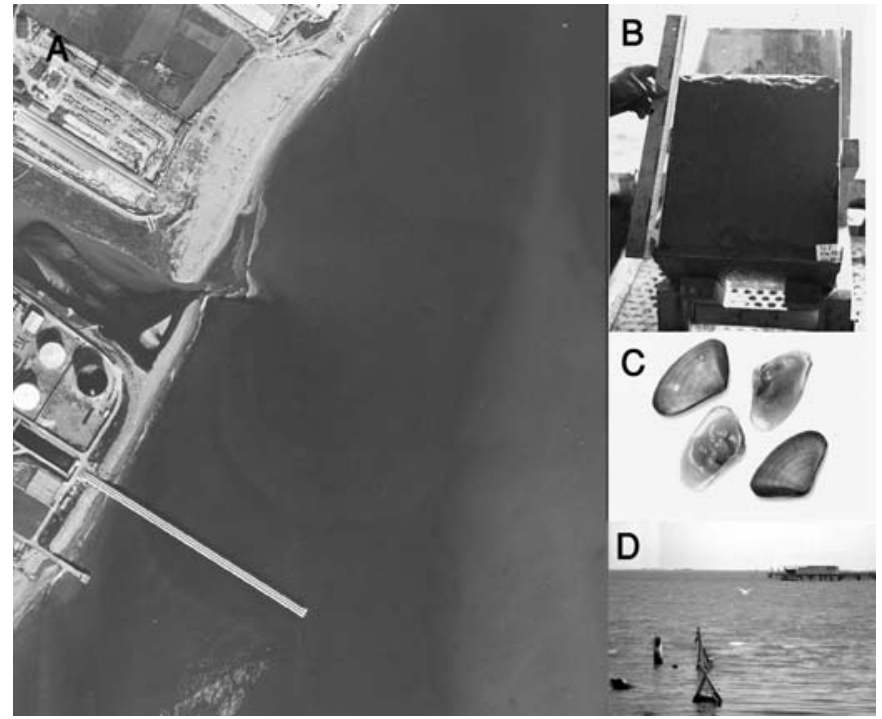

Figure 5.2. Fate of enteric viruses in coastal marine environments. A. A heavily polluted river with abundant particulate material discharges into the sea, B. undisrupted marine sediment with the fluffy top layer where viruses accumulate, C. coquina clams and other bivalves readily adsorb pathogenic viruses within their edible tissues, and D. shellfish grown in areas receiving urban sewage contamination is responsible for outbreaks of gastroenteritis and infectious hepatitis.

sewage effluents, unintentional discharges by urban and rural run-off, waste input from boats, and via rivers when the discharges take place in fresh water.

Mankind is exposed to enteric viruses in seawater mainly through the consumption of shellfish grown in contaminated waters, or to a lesser extent through recreational activities in sewage-polluted waters.

The type of treatment will ultimately determine the concentration of pathogens in treated sewage and sludge, and their relative risk of disposal. An overview of the fate of enteric viruses in coastal environments is depicted in Figure 5.2. Domestic sewage may be disposed of directly in the marine environment by coastal outfalls or by dumping from barges, and may occur in the form of raw sewage, treated effluent, or sewage sludge. Virus concentrations of 5000$100,000 \mathrm{PFU} / \mathrm{l}$ are commonly reported in raw sewage (Rao \& Melnick, 1986), and may be greatly reduced during treatment; however an average of 50-100 PFU/l are normally found in effluents from water treatment plants (Rao \& Melnick, 1986). In any case, viruses readily adsorb onto the abundant suspended solids present in sewage and are discharged solid-associated into marine environments (Fig. 5.2A). While viruses associated with small-size $(<3 \mu \mathrm{m})$ particulate material tend to float in the water column, viruses adsorbed onto large/medium $(>6 \mu \mathrm{m})$ particles readily settle down in the bottom sediment. Viruses accumulate in the loose fluffy top layer of the compact bottom sediment (Fig. 5.2B) and are thereby protected from inactivation by natural or artificial processes (Rao et al., 1986a; Sobsey et al., 1988). Sediments in coastal seawaters act as reservoirs from which viruses may be subsequently resuspended by several natural or artificial phenomena. Shellfish (Fig. 5.2C), being filter feeders, tend to concentrate viruses and bacteria in their edible tissues, and concentrations of these microorganisms in 
shellfish may be much higher than those in the surrounding water. Shellfish grown and harvested from waters receiving urban contaminants (Fig. 5.2D) have been implicated in outbreaks of viral diseases, notably viral hepatitis and gastroenteritis (Bosch et al., 2001; Christensen et al., 1998; Halliday et al., 1991; Kingsley et al., 2002; Le Guyader et al., 1996).

\subsubsection{Viruses in Seawater}

Viruses are potentially dangerous contaminants of the sea, as products of human activities. Table 5.2 lists some reports on the isolation of human enteric viruses in coastal and estuarine seawaters. Human pathogenic viruses are not only found in the millions of liters of variously treated human wastes dumped directly into coastal waters from sewage outfalls, but also from runoff from numerous storm drain sewers. Although the ocean offers relatively rapid dilution of treated sewage, it appears that dilution phenomena may not be enough to minimize the impact of virus pollution when contaminant affluents discharge at or within a short distance of the shoreline (Bosch et al., 1988a; Hugues et al., 1980). Based on this evidence, barges are employed to dump treated effluents at considerable distances from the shore. Nevertheless, sea bathing and water sport activities, which are becoming increasingly popular, may be nowadays not only expanded beyond the traditional summer seasons but also carried out at long distances from the shore. The full impact of viral pollution of recreational seawater on public health is hard to evaluate due to the technical and economical difficulties of virological studies. Nevertheless, epidemiology studies show significant risks associated with swimming near flowing storm drains. Specifically, the incidence of illnesses such as rashes, gastrointestinal disorders, and upper respiratory infections approximately doubled in those swimming at the mouth of a storm drain (Santa Monica Bay Restoration Project, 1996). Additionally, epidemiological data of waterborne illnesses also indicate that the common etiological agents are more likely to be viruses and parasitic protozoa than bacteria, and enteroviruses (polioviruses, coxsackie viruses, echoviruses), hepatitis $\mathrm{A}$ and $\mathrm{E}$, adenoviruses, rotaviruses, and noroviruses have all

Table 5.2. Examples of reported isolations of human enteric viruses in seawater.

\begin{tabular}{|c|c|c|c|}
\hline Site & Virus type & Virus numbers/liter & Reference \\
\hline Italy & Enteroviruses & 0.4 to $16 \mathrm{TCID}_{50}^{a}$ & De Flora et al., 1975 \\
\hline USA (Texas) & Enteroviruses & 0.01 to $0.44 \mathrm{PFU}^{b}$ & Goyal et al., 1979 \\
\hline USA (New York) & $\begin{array}{l}\text { Poliovirus } \\
\text { Echovirus }\end{array}$ & 0 to $2.1 \mathrm{PFU}$ & Vaughn et al., 1979 \\
\hline France & $\begin{array}{l}\text { Enteroviruses } \\
\text { Adenoviruses }\end{array}$ & 0.05 to $6.5 \mathrm{MPNCU}^{c}$ & Hugues et al., 1980 \\
\hline Spain & Enteroviruses & 0.12 to $1.72 \mathrm{MPNCU}$ & Finance et al., 1982 \\
\hline USA (Florida) & Enteroviruses & 0.05 to $0.14 \mathrm{PFU}$ & Schaiberger et al., 1982 \\
\hline Israel & Enteroviruses & 1 to $6 \mathrm{PFU}$ & Fattal et al., 1983 \\
\hline USA (Texas) & Enteroviruses & 0.06 to $0.026 \mathrm{PFU}$ & Rao et al., 1984 \\
\hline Spain & $\begin{array}{l}\text { Poliovirus } \\
\text { Echovirus }\end{array}$ & 0.12 to $0.15 \mathrm{MPNCU}$ & Lucena et al., 1985 \\
\hline USA (Texas) & Rotaviruses & 0.007 to $2.6 \mathrm{PFU}$ & Rao et al., 1986a \\
\hline
\end{tabular}

${ }^{a}$ TCID $_{50}$ : Tissue culture infectious dose S0. .

${ }^{b}$ PFU: Plaque forming units.

${ }^{c}$ MPNCU: Most probable number of cytopathic units. 
been associated with swimming-related illness (Cabelli et al., 1982; Fattal \& Shuval, 1989; Koopman et al., 1982; Moore et al., 1994; Seyfried et al., 1985).

In a routine study conducted on seawater, a widespread poliomyelitis vaccination program conducted in a coastal urban community was reflected in the levels of vaccinal poliovirus in seawater, which demonstrates that environmental monitoring of viruses provides useful evidence on the occurrence of infections, not only apparent but also unapparent, among the population (Lucena et al., 1986).

\subsubsection{Viruses in Marine Sediment}

Table 5.3 shows some examples of the occurrence of human enteric viruses in marine sediments. Viruses accumulate in the fluffy sediment where the concentrations may be 1010,000 times greater than those found in water. Sediments represent a reservoir from which viruses may spread when the sediments are disturbed and resuspended in the water column. Resuspension commonly occurs as a result of natural different phenomena, among which are storms, dredging, and tides (Van Donsel \& Geldreich, 1971). Resuspended solid-associated viruses can be transported from polluted to unpolluted recreational or shellfish growing waters and then pose health hazards (Rao et al., 1986a).

Obviously, the resuspension of the microorganisms has a more dramatic effect on the quality of the overlaying water in shallow estuarine water than in deep coastal water, where the impact would not be significant because of the dilution in the large volume of overlaying water (Schaiberger et al., 1982).

Viruses that may become associated with particulate material present in seawater survive for longer periods of time when adsorbed to sediments than when held in free suspension (De Flora et al., 1975; Rao et al., 1984, 1986a; Sobsey et al., 1988). Studies have indicated the presence of human enteric viruses in the sediments of polluted coastal waters (Bosch et al., 1988a; Bosch \& Pintó, 1992; De Flora et al., 1975; Rao et al., 1986a; Schaiberger et al., 1982).

Table 5.3. Examples of reported isolations of human enteric viruses in marine sediment.

\begin{tabular}{|c|c|c|c|}
\hline Site & Virus type & Virus numbers/kilogram & Reference \\
\hline Italy & $\begin{array}{l}\text { Enteroviruses } \\
\text { Reovirus }\end{array}$ & 0.4 to $40 \mathrm{TCID}_{50}^{a}$ & De Flora et al., 1975 \\
\hline USA (Florida) & Enteroviruses & 0 to $112 \mathrm{PFU}^{b}$ & Schaiberger et al., 1982 \\
\hline USA (Texas) & Enterovirus & 39 to $398 \mathrm{PFU}$ & Rao et al., 1984 \\
\hline USA (Texas) & Rotavirus & 800 to $3800 \mathrm{PFU}$ & Rao et al., 1986a \\
\hline Spain & Enterovirus & 5 to $73 \mathrm{PFU}$ & Bosch et al., 1988a \\
\hline Spain & $\begin{array}{l}\text { Enterovirus } \\
\text { Rotavirus }\end{array}$ & $\begin{array}{l}130 \text { to } 200 \mathrm{PFU} \\
57 \text { to } 140 \mathrm{FF}^{c}\end{array}$ & Jofre et al., 1989 \\
\hline Spain & Rotavirus Hepatitis, A virus & 0 to $560 \mathrm{FF},+\mathrm{RNA}^{d}$ & Bosch \& Pintó, 1992 \\
\hline France & $\begin{array}{l}\text { Enterovirus } \\
\text { Rotavirus } \\
\text { Hepatitis A virus }\end{array}$ & $\begin{array}{l}+ \text { RNA } \\
+ \text { RNA } \\
+ \text { RNA }\end{array}$ & Le Guyader et al., 1994 \\
\hline
\end{tabular}

\footnotetext{
${ }^{a}$ TCID $_{50}$ : Tissue culture infectious dose ${ }_{50}$.

${ }^{b}$ PFU: Plaque forming units.

${ }^{c}$ FF: Fluorescent foci.

${ }^{d}$ RNA detected by molecular hybridization.
} 
Human pathogenic viruses have been detected as far as $5 \mathrm{~km}$ from the shore and as deep as $82 \mathrm{~m}$ (Bosch et al., 1988a).

Usually, no correlation could be demonstrated between virus numbers and any bacterial parameter in marine sediment samples. This lack of correlation is probably due to the different decay rates shown by bacteria and viruses in the environment. Only in cases where the pollution may result from a recent deposition may viruses correlate with bacterial indicators (Bosch et al., 1988a).

An evaluation of the presence of viruses in marine sediment certainly provides an additional insight into the long-term water quality conditions of a given area.

\subsubsection{Virus Survival in the Sea}

It may be assumed that human and animal pathogens will suffer an aggressive treatment in the marine environment and will die-off within a short time. The phenomenon that selfpurification processes are more pronounced in seawater than in river water has been reported by several authors (Matossian \& Garabedian, 1967; Gironés et al., 1989). However, the selfdepuration capacity of marine water is finite. Yet the critical question is whether or not these viruses can survive long enough and in high enough concentration to cause disease in individuals who are in contact with polluted recreational water or who consume contaminated seafood.

The survival of viruses in the marine environment is reviewed in Chapter 16. Among the many factors affecting virus survival in the marine environment are temperature (Bosch et al., 1993), virus association to solids (Gerba \& Schaiberger, 1975; La Belle et al., 1980; Rao et al., 1984; Sobsey et al., 1988), and the presence of microbial flora (Gunderson et al., 1968; Fujioka et al., 1980; Toranzo et al. 1983; Gironés et al., 1989). It seems reasonable to assume that environmental factors and the compositional make-up of seawater may be substantially different from one geographical location to another, which implies that different data of virus persistence are produced when the same viral strain is suspended in water sampled from different sites (Bosch et al., 1993). Several observations demonstrate the potential involvement of native marine microorganisms in the inactivation of viruses in marine habitats, although data on the successful isolation of microorganisms with virucidal properties are scarce (Fujioka et al., 1980; Girones et al., 1990; Bosch et al., 1993). Additionally, the ability of bacteria to inactivate viruses is usually lost while subculturing the microorganisms in the laboratory, although in a few cases these bacteria could be subcultured for over 1 year without losing their antiviral activity (Girones et al., 1990; Bosch et al., 1993).

\subsection{VIRUSES IN SHELLFISH}

Several phenomena, such as flooding, treated and untreated polluted effluent discharges, or sewage runoff, can elevate microbial contaminants in shellfish habitats, and, since bivalves are filter feeders, these mollusks can become reservoirs of human pathogens. Other types of seafood such as crabs (Goyal, 1984) or shrimps (Botero et al., 1996) can accumulate viruses on their shells and carnivorous shellfish, such as lobsters or crabs, can feed on contaminated bivalves (Hejkal \& Gerba, 1981), but their role in the transmission of viral diseases is unproven.

Following the culinary tradition, bivalve shellfish is often consumed raw, like oysters and sometimes clams or cockles, or just lightly cooked, like most of other mollusks. This cooking 
Table 5.4. Examples of reported large (over 100 cases) outbreaks linked to shellfish consumption.

\begin{tabular}{lllcll}
\hline Year & Country & Shellfish & No. of cases & Responsible virus & Reference \\
\hline 1973 & USA & Oysters & 265 & HAV $^{a}$ & Mackowiak et al., 1976 \\
$1976-1977$ & Great Britain & Clams & 800 & SRSV $^{b}$ & Appleton \& Pereira, 1977 \\
1978 & Australia & Oysters & 2000 & NV $^{c}$ & Murphy et al., 1979 \\
1978 & Australia & Oysters & 150 & NV & Linco \& Grohmann, 1980 \\
$1980-1981$ & Great Britain & Cockles & 424 & NV & O'Mahony et al., 1983 \\
1982 & USA & Oysters & 472 & NV & Richards, 1985 \\
1983 & Great Britain & Oysters & 181 & SRSV & Gill et al., 1983 \\
1983 & Malaysia & Cockles & 322 & HAV & Goh et al., 1984 \\
1986 & USA & Clams & 813 & NV & Morse et al., 1986 \\
& & Oysters & 204 & & \\
1988 & Shanghai & Clams & 292301 & HAV & Halliday et al., 1991 \\
1999 & Spain & Clams & 183 & HAV & Bosch et al., 2001 \\
\hline
\end{tabular}

${ }^{a}$ HAV: Hepatitis A virus.

${ }^{b}$ SRSV: Small round structured viruses.

${ }^{c} \mathrm{NV}$ : Norovirus.

habit, together with the fact that the whole animal including viscera is consumed, poses a major public health concern since shellfish act like passive carriers of human pathogenic viruses. Generally, commercial growth of shellfish species takes place in shallow, in-shore waters, which may receive occasional sewage pollution. The consumption of shellfish is very clearly linked to the transmission of enteric infections and epidemics have been recorded since medieval times in many countries (Lees, 2000). These outbreaks are normally caused by shellfish collected by unscrupulous professionals or careless private individuals, from areas where harvesting is prohibited. However, they also occur as a result of eating shellfish from authorized shellfishproducing areas, when these areas have been temporarily polluted (Mackowiak et al., 1976) and sanitary controls fail to provide a safe indication of viral pollution.

The first reported association of viruses with shellfish-borne gastroenteritis infection was observed in the winter of 1976-1977 in the United Kingdom when cockles were epidemiologically linked to 33 incidents affecting nearly 800 people (Appleton \& Pereira, 1977). SRSV particles, like those seen in outbreaks of winter vomiting disease, were observed by electron microscopy in a high proportion of patients feces. Regardless of the variety of healthsignificant viruses found in shellfish, norovirus and hepatitis A virus are the most relevant viral pathogens involved in shellfish-borne diseases (Table 5.4). Norovirus infections represent the vast majority of shellfish-related outbreaks, and hepatitis A is the most serious infectious disease caused by shellfish consumption. The United States Food and Drug Administration risk assessments estimate cases of norovirus gastroenteritis related to seafood consumption at some 100,000 per year (Williams \& Zorn, 1997), and epidemics of hepatitis A caused by food occur 10 times more often than those caused by water, shellfish being the cause of more than $50 \%$ of reported cases (Cliver, 1985). Nevertheless, no shellfish-borne outbreak ever had the magnitude of the one reported in Shanghai in 1988, caused by hairy clams (Halliday et al., 1991).

Bioaccumulation of viruses in the shellfish digestive tract is a very rapid phenomenon. Viruses are readily adsorbed to shellfish tissue within 1-h contact time and maximum virus levels may be observed after $6 \mathrm{~h}$ (Abad et al., 1997a). Adsorption of viruses on substrates such as feces, kaolinite, or unicellular algae considerably increases shellfish accumulation 
efficiency (Metcalf et al., 1979). Commercial heat treatment (cooking) is employed to reduce the levels of microbial contaminants in shellfish. Heat can render many viruses noninfectious; however the degree of cooking required to reliably inactivate viruses would probably render oysters unpalatable to consumers (McDonnell et al., 1997). Laboratory studies show that enteric viruses and notably hepatitis A virus may be found in cooked shellfish (Abad et al., 1997). In addition, outbreaks of gastroenteritis and hepatitis have been linked to consumption of commercially cooked cockles (Appleton \& Pereira, 1977; Kohn et al., 1995).

Most countries have endorsed sanitary controls on live bivalve shellfish. In the European Union, these are covered by Council Directive 91/492/EEC (Anonymous, 1991) and in the United States, by interstate trading agreements set out in the Federal Drug Administration National Shellfish Sanitation Program Manual of Operations (Anonymous, 1993). These regulations cover similar ground on the requirements, among others, for harvesting area classification, depuration, relaying, analytical methods, and provisions for suspension of harvesting from classified areas following a pollution or public health emergency. A major weakness of these controls is the use of traditional bacterial indicators of fecal contamination, such as the fecal coliforms or Escherichia coli, to assess contamination and hence implement the appropriate control measures. Fecal indicators are either measured in the shellfish themselves (EU perspective) or in the shellfish-growing waters (US FDA perspective). However, several reports describe a lack of correlation between bacterial indicator microorganisms and viruses, and pathogenic viruses may be detected in shellfish from areas classified as suitable for commercial exploitation according to fecal coliform criteria (Abad et al., 1997a; Lees, 2000; Le Guyader et al., 2000). The guidelines establish that shellfish meeting a microbiological standard of less than $230 \mathrm{E}$. coli or 300 fecal coliforms in $100 \mathrm{~g}$ of shellfish flesh can be placed on the market for human consumption. Human enteric viruses, e.g. rotavirus and hepatitis A virus, have been detected in shellfish which were adequate for public consumption according to criteria based on the numbers of bacterial indicators (Jofre et al., 1993; Bosch, et al., 1994; Le Guyader et al., 2000; Romalde et al., 2002). Additionally, hepatitis A and gastroenteritis outbreaks have been associated with the consumption of shellfish meeting legal standards (Bosch et al., 2001; Le Guyader et al., 1996; Lees, 2000; Mele et al., 1989).

The legislation also requires that third country imports into the EU and USA have to be produced to the same standard as domestic products. Exporting nations have therefore developed programs for compliance with the regulations of their target export markets. Nevertheless, a number of examples of trans-national outbreaks have recently been reported following trade between EU Member States (Christensen et al., 1998) and importation of shellfish from third countries into the EU and the USA (Bosch et al., 2001; Sánchez et al., 2002; Kingsley et al., 2002).

Conventional commercial processes employed to purge out the microbial contamination of live bivalves are depuration, performed in tanks, and relaying, performed in the natural environment. Tank-based depuration is now widely practiced in many European countries, while it is less widely used in the USA (Lees, 2000; Otwell et al., 1991). Depuration periods may vary from 1 to 7 days, since minimum time periods for depuration are not stipulated in the legislation, with around 2 days being probably the most widely used period.

Early studies, using artificially spiked soft shell clams, reported that most viruses were purged within a $24-48$-h period, and that low levels of viruses were depurated more rapidly than high levels (Metcalf et al., 1979). More recent studies show that although depuration 
and relaying procedures may be insufficient to completely remove viruses (Abad et al., 1997a; Lees, 2000; Richards, 1988), they do contribute to reduce virus levels and hence the risk of infection due to shellfish consumption (Bosch et al., 1994). Process temperature appears as an important factor for effective virus removal (Dore et al., 1998; Jaykus et al., 1994; Power \& Collins, 1990), although a raise in depuration temperature may result in increased shellfish mortality. Nevertheless, epidemiological evidence reveals that enteric viruses can be transmitted to mankind after consuming shellfish which has been depurated (Gill et al., 1983; Heller et al., 1986; Sockett et al., 1993). Once again compliance with bacterial end-product standards does not provide a guarantee of virus absence, and bacterial depuration rates cannot accurately predict virus removal rates.

\subsection{METHODS OF VIRUS DETECTION}

\subsubsection{Virus Concentration from Seawater and Marine Sediment}

The basic steps of the virological analysis of seawater are sampling, concentration, decontamination/removal of inhibitors, and specific virus detection. Concentration is a particularly critical step since the viruses may be present in such low numbers that concentration of the water samples is indispensable to reduce the volume to be assayed for viruses to a few milliliters or even microliters. A good concentration method should fulfill several criteria: it should be technically simple, fast, provide high virus recoveries, be adequate for a wide range of enteric viruses, provide a small volume of concentrate, and be inexpensive. Table 5.5 shows a broad selection of currently available and widely employed procedures; some of them require large equipment. Details on virus concentration procedures have been published elsewhere (American Public Health Association, 1998; Environmental Protection Agency, 1984). In relatively nonpolluted marine waters, the virus levels are likely to be so low that optimally hundreds, or even thousands, of liters should be sampled to increase the probability of virus detection. Nevertheless, all available methodologies have important limitations. The efficiency

Table 5.5. Procedures for the concentration of viruses from seawater.

\begin{tabular}{|c|c|}
\hline Principle & References \\
\hline \multicolumn{2}{|c|}{ Adsorption-elution methods } \\
\hline Negatively charged filters & Farrah et al., 1977 \\
\hline Positively charged filters & Sobsey \& Jones, 1979 \\
\hline Glass powder & $\begin{array}{l}\text { Gajardo et al., 1991; Sarrette et al., 1977; } \\
\text { Schwartzbrod \& Lucena, } 1978\end{array}$ \\
\hline Glass fiber & Vilaginès et al., 1997 \\
\hline Aluminum hydroxide & Wallis \& Melnick, 1967 \\
\hline \multicolumn{2}{|c|}{ Precipitation methods } \\
\hline Organic flocculation & Katzenelson et al., 1976 \\
\hline Ammonium sulfate precipitation & Bosch et al., 1988b; Shields \& Farrah, 1986 \\
\hline Polyethylene glycol hydroextraction & Farrah et al., 1978; Lewis \& Metcalf, 1988 \\
\hline Ultracentrifugation & Mehnert et al., 1997; Steinman, 1981 \\
\hline Lyophilization & Gajardo et al., 1995; Pintó et al., 2001 \\
\hline Ultrafiltration & Divizia et al., 1989 \\
\hline
\end{tabular}


of a virus concentration method widely depends on the quality of the sampled water. Usually, all available procedures have been basically evaluated in spiked samples, and the recovering efficiencies recorded with experimentally contaminated water dramatically decrease when the method is applied in actual field trials. Additionally, none of the existing concentration procedures has been tested with all the groups of medically important viral pathogens; normally, a few specific enteric viruses have been employed to conduct the evaluation trials. However, some virus concentration methods have been used successfully to recover naturally occurring enteric viruses in seawater (Environmental Protection Agency, 1984; Finance et al., 1982; Gerba \& Goyal, 1982; Goyal \& Gerba, 1983; Henshilwood et al., 1998; Lewis \& Metcalf, 1988; Rao et al., 1986a).

Most of the procedures for concentrating and extracting viruses make use of the properties of the viral proteinaceous macromolecules. Certain protein structures confer on viruses in an aquatic environment the properties of a hydrophilic colloid of an amphoteric nature whose electric charge varies according to the $\mathrm{pH}$ and the ionic force of the environment. Viruses can therefore be adsorbed onto and then detach themselves from different substrates which are positively or negatively charged depending on their $\mathrm{pH}$. Methods based on the adsorption of viruses from the sampled water onto a suitable solid surface from which they may be subsequently eluted into a much smaller volume are recommended for their use with largevolume samples.

Different types of filters have been proposed for the recuperation of aquatic viruses, in the form of flat membranes or cartridges. Cartridge-type filters have the advantage of allowing filtration of large volumes of moderately turbid water within relatively short time. Their chemical composition, diameter, and porosity vary enormously. A whole range of "negatively" or "positively" charged filters now exist. Their efficiency depends on the type of water being treated and the presence of interfering substances such as detergents, suspended solid matter, or organic matter which can affect the adsorption of the viruses on these filters (Sobsey \& Glass, 1984; Sobsey \& Hickey, 1985).

Negatively charged membranes or cartridges (Farrah et al., 1976; Wallis \& Melnick, 1967) have the drawback that the water samples must be pretreated, i.e., the water has to be acidified and often salts need to be added to facilitate adsorption since electronegative filters do not adsorb viruses well under ambient water conditions (Rao \& Melnick, 1986), and this limits the on-location use of this method to a great extent. However automatic injection systems do exist for treating several hundred liters of water. Virus concentration with electropositive filters may be performed on location, at ambient conditions, without any prior amendment of the sample, which make this procedure most suited for in-field studies, provided that the sample $\mathrm{pH}$ is lower than 8.5 (Sobsey \& Jones, 1979). Glass powder (Gajardo et al., 1991; Sarrette et al., 1977; Schwartzbrod \& Lucena, 1978) or glass fiber (Vilaginès et al., 1997) has also been satisfactorily used in different laboratories as adsorbent materials for virus concentration.

Viruses in eluate volumes too large to be conveniently and economically assayed directly for specific virus detection, such as those obtained from processing large volumes of water through cartridge or large disk filters, can be reconcentrated by several alternative methods. Recovery of small quantities of viruses from natural waters is dependent not only on the efficacy of primary concentration from the original large volume, but also on the reconcentration of the primary eluate to a smaller volume.

Methods such as aluminum hydroxide adsorption-precipitation (Wallis \& Melnick, 1967), polyethylene glycol hydroextraction (Farrah et al., 1978; Lewis \& Metcalf, 1988), organic 
flocculation (Katzenelson et al., 1976), and ammonium sulfate precipitation (Bosch et al., 1988; Shields \& Farrah, 1986) that are impractical for processing large fluid volumes are however suitable for second-step concentration. Alternatively for reconcentration, viruses can also be sedimented depending on their molecular weight, and certain methods of concentration, such as ultracentrifugation (Mehnert et al., 1997; Steinman, 1981), take advantage of this characteristic.

Freeze-drying of samples (Gajardo et al., 1995; Pintó et al., 2001) and rehydration in a smaller volume provides a procedure for both virus concentration and removal of inhibitors, if molecular procedures are employed for virus detection.

Ultrafiltration (Divizia et al., 1989) can utilize size exclusion rather than adsorption and (or) elution to concentrate viruses and, therefore, can provide consistent recoveries among different viruses and widely varying water conditions.

Since an evaluation of the presence of viruses in sediment provides an additional insight into long-term water quality conditions, several methods for the detection of viruses have been developed. These methods basically consist of an elution of the viruses from the solid materials and an ulterior concentration of the eluted viruses. Viruses are usually eluted from the marine sediments by using alkaline buffers (Bosch et al., 1988a; Gerba et al., 1977; Jofre et al., 1989), or by the action of caotropic agents (Jofre et al., 1989; Lewis \& Metcalf, 1988; Wait \& Sobsey, 1983). Precipitation methods based on organic flocculation (Wait \& Sobsey, 1983), ammonium sulfate flocculation (Jofre et al., 1989), polyethylene precipitation (Lewis \& Metcalf, 1988), or ultrafiltration (Gerba et al., 1977) are procedures commonly employed to concentrate viruses from the eluate.

\subsubsection{Virus Recovery from Shellfish}

Virus detection in shellfish has to overcome several difficulties. On the one hand, viruses are expected to be present in shellfish in very low numbers, which nevertheless are sufficient to pose a health risk. This low virus load implies the use of methodologies yielding a high efficiency of virus recovery from shellfish tissues. On the other hand, shellfish extracts are both highly cytotoxic and not adequate to be inoculated in cell cultures for the detection of culturable viruses, and not compatible either with polymerase chain reaction (PCR) based methodologies for the detection of nonculturable viruses, particularly if a reverse transcription must be previously performed (RT-PCR). The key objective is then to develop procedures for shellfish analysis which result in a low volume of a noncytotoxic or, even better nowadays, highly pure nucleic acid preparation with no inhibitory effect to the PCR. As a matter of fact, in this latter case, the degree of virus detection effectiveness achieved after RT-PCR is essentially the result of two related factors: the efficiency of recovery of the extraction procedure applied to the shellfish sample and the degree of final purity of the recovered virus.

Table 5.6 lists different procedures for the processing of shellfish samples prior to the specific virus detection, essentially by molecular procedures since the most relevant shellfishborne viral pathogens are nonculturable. The first decision is to choose between performing virus detection in dissected shellfish tissues or in whole shellfish meats. Studies on the localization of human enteric viruses in shellfish tissues revealed that most of the virus could be found in the stomach and digestive diverticula (Abad et al., 1997a; Romalde et al., 1994). Atmar and co-workers reasoned that removal of these organs for virus extraction might simplify and shorten the time needed to purify viral nucleic acid for RT-PCR (Atmar et al., 1996). Testing the stomach and digestive gland for virus detection presented several advantages in comparison 
Table 5.6. Procedures for processing of shellfish samples prior to virus detection by RT-PCR.

\begin{tabular}{lll}
\hline Process & Method & Reference \\
\hline Virus elution & Chloroform-butanol/cat-floc elution & Atmar et al., 1996 \\
& Vertrel extraction & Mendez et al., 2000 \\
Virus concentration & Organic flocculation & Sobsey et al., 1978 \\
& Centrifugation & Sobsey et al., 1978 \\
& Ultracentrifugation & Loisy et al., 2000 \\
RNA extraction & PEG precipitation & Lewis \& Metcalf, 1988; Atmar et al., 1995 \\
& Guanidium thiocyanate & Boom et al., 1990; Lees et al., 1994 \\
& Cetyltrimethyl ammonium bromide & Atmar et al., 1995; Jaykus et al., 1994 \\
& Commercial nucleic acid extraction kits & Loisy et al., 2000; Schwab et al., 2000; \\
& & Shieh et al., 1999 \\
\hline
\end{tabular}

with testing whole shellfish: less time-consuming procedure, increased test sensitivity, and decrease in the sample-associated interference with RT-PCR.

Following virus extraction, a variety of subsequent nucleic acid extraction and purification protocols may be employed (Table 5.6). Due to the small size of the PCR reaction volumes, a reconcentration step is incorporated prior to the molecular assay. Nucleic acid purification based on virus lysis with guanidine and recovery with a silica matrix (Boom et al., 1990; Lees et al., 1994), or, alternatively, the use of organic solvents for purification, followed by nucleic acid precipitation using cetyltrimethyl ammonium bromide (CTAB) (Atmar et al., 1995; Jaykus et al., 1994), remain the procedures of choice. However, a wide variety of commercial kits have been applied for nucleic acid purification, offering reliability combined with convenience (Loisy et al., 2000; Schwab et al., 2000; Shieh et al., 1999).

\subsubsection{Specific Virus Detection Procedures}

Not too long ago, methods for the detection of viral pathogens were restricted to assays for culturable viruses, focused almost entirely on enteroviruses, and the BGM cell line has been for long the choice for infectivity assays of enteroviruses in environmental samples (Bosch, 1998; Morris \& Waite, 1980; Rao et al., 1986b). Despite that enteroviruses do not appear as epidemiologically relevant environmental contaminants; it will remain important to gather data on their occurrence in the environment until the global eradication of poliomyelitis becomes a reality. However, for this latter purpose, molecular tools provide better perspectives than cell culture techniques.

Wild-type rotaviruses present difficulties in their in vitro replication, although most isolates may be adapted to grow in several cell lines such as the monkey kidney cell line MA104 or the human intestinal cell line CaCo-2 (Kitamoto et al., 1991). The standard methods for the diagnosis of specific infectious rotaviruses involve immunofluorescence tests and optical microscopic counting of infected foci in the culture (Bosch et al., 1988b; Hejkal et al., 1984; Smith \& Gerba, 1982). A further refinement in this direction was the use of flow cytometry for the detection of fluorescent foci in rotavirus infected cells (Abad et al., 1998). Flow cytometry is applicable for the detection of rotaviruses in environmental samples through an automatable and standardizable procedure, much less cumbersome than direct optical microscopy screening of cell cultures for fluorescent foci. 
The advent of molecular techniques for virus detection, and particularly reverse transcriptase-polymerase chain reaction (RT-PCR), provided exquisite tools for the detection of fastidious health-significant viruses in the water environment. Health-significant viruses, which were previously unrecognizable because they replicate poorly or do not at all in cell cultures, became detectable with nucleic acid based techniques. Environmental virologists initially employed hybridization assays which have been more recently replaced by PCRbased procedures (Bosch et al., 1996; Jaykus et al., 1996; Jothikumar et al., 1995; Le Guyader et al., 1994; Lees et al., 1994; Pintó et al., 1996; Schwab et al., 1995; Villena et al., 2003). Enhanced detection sensitivity, a significant advantage in environmental virology, may be achieved through nested approaches (Dore et al., 1998; Green et al., 1998; Le Guyader et al., 1994). However, the fact that nested PCR may represent a frequent cause of carryover contamination should not be neglected.

An additional difficulty is that traditional virus concentration systems from water or shellfish extraction procedures are not always compatible with RT-PCR detection: inhibitory substances are concentrated and recovered along with the viruses. A great variety of procedures have been developed for the removal of inhibitors, which include dialysis, solvent extraction, proteinase treatments, lyophilization, gel or glass filtration, nucleic acid adsorption or precipitation, antibody capture, and the use of commercial kits (Abbaszadegan et al., 1993; Atmar et al., 1995; Graff et al., 1993; Jaykus et al., 1996; Loisy, et al., 2000; Schwab et al., 2000; Shieh et al., 1999; Tsai et al., 1993). The rule of thumb is that the degree of final purity of the assayed sample greatly determines the sensitivity of PCR, or particularly, RT-PCR virus detection.

One limitation of molecular techniques is that they fail to discern between infectious and noninfectious particles which may be of critical relevance in environmental virology (Abad et al., 1994; Gassilloud et al., 2003). All enteric viruses of public health concern bear RNA genomes. In studies employing RT-PCR, it has been shown that poliovirus genomic RNA is not stable in nonsterilized seawater (Tsai et al., 1995). While free DNA is fairly stable, it is unlikely that a free single-stranded RNA genome like those of noroviruses or hepatitis A virus would remain stable without its protein coat in the marine environment. This presumption is less clear for the double-stranded RNA genome of rotaviruses.

One possibility of solving this problem may be the use of cell lines susceptible to support the propagation of a wide variety of enteric viruses, enabling the amplification of virus sequences in cell culture prior to detection by PCR, accomplishing the dual purpose of increasing the number of copies of target nucleic acid and of incorporating an infectivity assay as well (Ma et al., 1994; Pintó et al., 1995). This approach has been reported for detection of infectious astrovirus (Abad et al., 1997b) and enterovirus (Murrin \& Slade, 1997; Reynolds et al., 1996). Whenever possible, the use of a combined cell culture-RT-PCR procedure utilizes the major advantages of the separate methodologies, while overcoming many of their disadvantages. The inclusion of an infectivity test prior to the specific detection solves not only this latter point but also the lack of sensitivity required for some types of samples such as environmental samples.

However, combined cell culture-RT-PCR methods are not applicable to the unculturable caliciviruses or to most hepatitis A virus isolates. An alternative approach is to employ an antibody capture RT-PCR. This has been applied to detection of hepatitis A virus in seeded shellfish samples and shown to be both sensitive and useful for removal of RT-PCR inhibitors as well (Deng et al., 1994; Graff et al., 1993; López-Sabater et al., 1997). Since recognition by 
a conformationally dependent monoclonal antibody is lost when the particle conformation is altered, coupling of the molecular procedure with capture with this type of antibody may enable to discern between intact and altered virions. This approach may prove useful for other enteric viruses, provided that adequate immunological reagents for the most relevant viral pathogens are available. For this purpose, recombinant virus-like particles, which can be obtained in very high numbers in in vitro expression systems (Crawford et al., 1994; Lawton et al., 1997), may be employed for the production of antibodies of non culturable viruses.

Many potential users may find PCR cumbersome, since a single test entails many different manual steps, and will consider the technique as suitable only for academic or reference labs, and inadequate for routine monitoring. However, over the last decade, PCR technology improved on several fronts. On the one hand, commercial PCR systems significantly ameliorated convenience, and have been quickly adopted for diagnostic laboratories. Nevertheless, the most dramatic improvement comes from the emergence of combined rapid thermocycling and fluorescence monitoring of amplified product, collectively referred to as "rapid-cycling real-time PCR" (Cockerill, III \& Smith, 2002; Gardner et al., 2003; Gassilloud et al., 2003; Kageyama et al., 2003), together with nucleic-acid-sequence-based amplification or NASBA techniques (Jean et al., 2001; Yates et al., 2001), both of which are now applicable in several commercially available systems. These procedures enable not only qualitative determination but also, and particularly, quantitative diagnostic assays. Although the generic determination of pathogens is the essence of diagnostic practices, the possibility to quantitatively detect virus agents represents a seminal refinement in routine monitoring virology.

\subsection{THE PROSPECTS FOR VIRUS STUDIES IN SEAWATER AND SHELLFISH}

The last two decades of virological research have contributed to significant progresses in the field of medical virology. These include the development of methodologies for the detection and characterization of nonculturable waterborne and foodborne viruses, the recognition of waterborne outbreaks caused by hepatitis $\mathrm{A}$ and $\mathrm{E}$ viruses, the consideration of rotavirus as the single most important cause of severe children gastroenteritis and norovirus as the most frequent agent of foodborne diarrhea, the characterization of other important agents of nonbacterial gastroenteritis such as astroviruses, sappoviruses, adenoviruses, and the assessment of the zoonotical transmission of some of the aforementioned agents.

Molecular characterization of environmental virus isolates provides tools to acquire an overview of the epidemiology of viruses circulating in the community and, at the same time, unveil the occurrence of asymptomatic infections. Limitations of this approach are important environmental virology issues such as the differential stability of a given virus type could give rise to a certain level of distortion in the produced data, and the kind of sample analyzed: only those viruses that are more prevalent in the population, and thus excreted in higher numbers, are likely to be detected.

Nucleic-acid-amplification-based techniques have been, and undoubtedly will continue to be, a major step forward in virus monitoring in environmental samples, and specially in shellfish and shellfish waters. One major drawback is that current published methods are diverse, complex, poorly standardized, and restricted to a few specialist laboratories. Standardized PCR assays for detection of public health relevant viruses as hepatitis A virus and 
norovirus are needed to be used in a routine diagnostic context. However, for this purpose, molecular techniques for the virological analysis must put in practice unique or additional quality assurance and quality control requirements to ensure that the data generated are useful and reliable. Some laboratories already have their own internal criteria for quality assurance but a consistent set of quality assurance procedures should be implemented in order to generate data that could be comparable and reliable. A major obstacle for acceptance of molecular techniques by regulatory agencies is in particular a lack of confidence on data generated without adequate controls.

Availability of quantitative and standardized virus methods will enable the future setting of legislative virus standards for bathing waters, bivalve shellfish, and shellfish growing waters. Achievement of this objective will also enable the identification of key environmental factors, such as rainfall and sewage discharges, responsible for viral contamination in bathing and shellfish harvesting areas. Identification, and management, of such critical control points will provide an alternative approach to containing the virus risk and would permit the development of enhanced sanitary controls.

In the meantime and due to technical difficulties, tests for most of these viruses remain restricted to laboratories with sophisticated facilities and well-trained personnel. On the other hand, it is impracticable to monitor the presence of all viral pathogens in the environment. The unreliability of bacterial model mcroorganisms led to the search for alternatives, and several bacteriophage groups appear as promising candidates, among which are somatic coliphages (IAWPRC Study Group on Health Related Water Microbiology, 1991), F+ specific (male-specific), RNA bacteriophages (Havelaar, 1993), and Bacteroides fragilis bacteriophages (Tartera \& Jofre, 1987), all of them with available ISO (International Standardization Office) procedures for their detection in water. $\mathrm{F}+$ phages in particular have been described as promising candidates to evaluate the virological quality of shellfish (Chung et al., 1998; Lees, 2000). Several studies have shown a correlation between the elimination kinetics of F+ RNA phages and those of enteric viruses (Dore \& Lees, 1995; Power \& Collins, 1989, 1990). F+ RNA phages were considered for inclusion in EU legal standards for live bivalve mollusk purification. Nevertheless reports on discrepancies in the occurrences of $\mathrm{F}+$ phages and pathogenic viruses are frequent. In shellfish associated with a large outbreak of hepatitis A reported in the East of Spain in 1999, with 184 serologically confirmed cases, the discrepancy observed between hepatitis A virus and $\mathrm{F}+$ phages was $55 \%$, while a $50 \%$ discordance was ascertained between generic enteric virus occurrence and F+ presence (Bosch et al., 2003). In another study comparing the validity of $E$. coli, enterovirus, and F+ RNA bacteriophages as indicator microorganisms, the phages failed to predict the risk of viral illness (Miossec et al., 2001). Additionally, when the comparative positivity for human enteric viruses and F+ RNA phages was investigated in 101 randomly chosen shellfish samples from South and West coast of France, a good correlation between the occurrence of enteric viruses and $\mathrm{F}+$ phages was observed in only $49 \%$ of the samples (Le Guyader, unpublished results). Forty one percent of these samples were positive for at least one type of enteric virus but negative for $\mathrm{F}+$ phages, while $11 \%$ of the samples were found to be negative for enteric viruses but positive for $\mathrm{F}+$ phages. At the time of publication of this work, F+ RNA phages have been removed from EU standards for shellfish purification.

Exhaustive studies are still required to ascertain the validity of a candidate indicator in a given scenario. In the end we should probably give up our hopes of finding a "universal" indicator for viruses, applicable to all situations, and resign ourselves to the use of particular indicator, index, or model microorganisms for specific purposes. 
Finally, another long-time challenge in environmental virology is to conduct actual field studies to evaluate the environmental behavior of human enteric viruses, which has to face the impossibility of introducing pathogens in the environment.

As model systems, recombinant tracers could be perfectly adequate for field studies of microbial tracking, since they may be produced in extremely high numbers (several milligram amounts). Additionally, their noninfectious nature makes them completely harmless and suitable to be used in scenarios where the use of actual viruses is hampered by the impossibility of introducing potential pathogens into, for instance, shellfish growing waters. Recombinant virus-like particles have been employed to investigate the influence of electrostatic interactions in the filtration of norovirus in quartz sand (Redman et al., 1997) and the behavior of rotaviruses in disinfection studies (Caballero et al., 2004).

Obviously, from the strictly structural point of view, there is no better surrogate of an actual virus pathogen to track their behavior in the environment than a noninfectious virus-like particle of the same virus.

\section{REFERENCES}

Abad, F.X., Pintó, R.M., \& Bosch, A. (1998). Flow cytometry detection of infectious rotavirus in clinical and environmental samples. Appl Environ Microbiol 64, 2392-2396.

Abad, F.X., Pintó, R.M., Diez, J.M., \& Bosch, A. (1994). Disinfection of human enteric viruses in water by copper and silver in combination with low levels of chlorine. Appl Environ Microbiol 60, 2377-2383.

Abad, F.X., Pintó, R.M., Gajardo, R., \& Bosch, A. (1997a). Viruses in mussels: Public health implications and depuration. J Food Prot 60, 677-681.

Abad, F.X., Pintó, R.M., Villena, C., Gajardo, R., \& Bosch, A. (1997b). Astrovirus survival in drinking water. Appl Environ Microbiol, 63, 3119-3122.

Abbaszadegan, M., Huber, M.S., Gerba, C.P., \& Pepper, I.L. (1993). Detection of enteroviruses in groundwater with the polymerase chain reaction. Appl Environ Microbiol 59, 1318-1324.

American Public Health Association (1998). Standard Methods for the Examination of Water and Wastewater, 20th edition. American Public Health Association, American Water Works Association, Water Pollution Control Federation, Washington, DC.

Anonymous (1991). Council Directive of 15th July 1991 laying down the health conditions for the production and placing on the market of live bivalve molluscs (91/492/EEC). Off J Eur Commun 268, 1-14.

Anonymous (1993). National Shellfish Sanitation Program, Manual of Operations. 1993 Revision. US Department of Health and Human Services, Public Health Service, Food and Drug Administration.

Appleton, H., \& Pereira, M.S. (1977). A possible virus aetiology in outbreaks of food poisoning from cockles. Lancet 1, 780-781.

Atmar, R.L., Neill, F.H., Romalde, J.L., Le Guyader, F., Woodley, C.M., Metcalf, T.G., \& Estes, M.K. (1995). Detection of Norwalk virus and hepatitis A virus in shellfish with the PCR. Appl Environ Microbiol 61, 30143018.

Atmar, R.L., Neill, F.H., Woodley, C.M., Manger, R., Fout, G.S., Burkhardt, W., Leja, L., McGovern, E.R., Le Guyader, F., Metcalf, T.G., \& Estes M.K. (1996). Collaborative evaluation of a method for the detection of Norwalk virus in shellfish tissues by PCR. Appl Environ Microbiol 62, 254-258.

Boom, R., Sol, C.J.A., Salimans, M.M.M., Jansen, C.L., Wertheim-van Dillen, P.M.E., \& Van der Noordaa, J. (1990). Rapid and simple method for purification of nucleic acids. J Clin Microbiol 28, 495-503.

Bosch, A. (1998). Human enteric viruses in the water environment: A minireview. Int Microbiol 1, 191-196.

Bosch, A., Abad, F.X., Gajardo, R., \& Pintó, R.M. (1994). Should shellfish be purified before public consumption? Lancet 344, 1024-1025.

Bosch, A., Gajardo, R., Díez, J.M., \& Pintó, R.M. (1996). Non isotopic automatable molecular procedures for the detection of enteroviruses. Mol Cell Probes 10, 81-89.

Bosch, A., Gray, M., Diez, J.M., Gajardo, R., Abad, F.X., Pintó, R.M., \& Sobsey, M.D. (1993). The survival of human enteric viruses in seawater. MAP Technical Rep Ser 76, 1-7. 
Bosch, A., Lucena, F., Diez, J.M., Gajardo, R., Blasi, M., \& Jofre, J. (1991). Waterborne viruses associated with a hepatitis outbreak. J Am Water Works Assoc 83, 80-83.

Bosch, A., Lucena, F., Girones, R., \& Jofre, J. (1988a). Occurrence of enterovirus on marine sediment along the coast of Barcelone (Spain). Can J Microbiol 34, 921-924.

Bosch, A., \& Pintó, R.M. (1992). Human enteric viruses in the environment. In A.Z. Keller \& H.C. Wilson (eds), Environmental Protection. University of Bradford Press, Bradford, vol. 3, pp. 63-71.

Bosch, A., Pintó, R.M., Blanch, A.R., \& Jofre, J. (1988b). Detection of human rotavirus in sewage through two concentration procedures. Water Res 22, 343-348.

Bosch, A., Sánchez, G., Le Guyader, F., Vanaclocha, H., Haugarreau, L., \& Pintó, R.M. (2001). Human enteric viruses in coquina clams associated with a large hepatitis A outbreak. Water Sci Technol 43, 61-66.

Bosch, A., Sánchez, G., Pintó, R.M., Abad, F.X., Pommepuy, M., \& Le Guyader, F.S. (2003) Methods for virus detection in molluscs. Validation and standardization. In A. Villalba, B. Reguera, J.L. Romalde, and R. Beiras (eds), Molluscan Shellfish Safety. Consellería de Pesca e Assuntos Marítimos da Xunta de Galicia \& Intergovernmental Oceanographic Commission of UNESCO, Santiago de Compostela, pp. 333-340.

Botero, L., Montiel, M., \& Porto, L. (1996). Enteroviruses in shrimp harvested from contaminated marine waters. Int J Environ Health Res 6, 103-108.

Caballero, S., Abad, F.X., Loisy, F., Le Guyader, F.S., Cohen, J., Pintó, R.M., \& Bosch, A. (2004). Rotavirus viruslike particles as surrogates in environmental persistence and inactivation studies. Appl. Environ. Microbiol. 70, 3904-3909.

Cabelli, V.J., Dufour, A.P., McCabe, L.J. \& Levin, M.A. (1982). Swimming-associated gastroenteritis and water quality. Am J Epidemiol 115, 606-616.

Christensen, B.F., Lees, D., Wood, K.H., Bjergskov, T., \& Green, J. (1998). Human enteric viruses in oysters causing a large outbreak of human food borne infection in 1996/97. J Shellfish Res 17, 1633-1635.

Chung, H., Jaykus, L.A., Lovelace, G., \& Sobsey, M.D. (1998). Bacteriophages and bacteria as indicators of enteric viruses in oysters and their harvest waters. Water Sci Technol 38, 37-44.

Cliver, D.O. (1985). Vehicular transmission of hepatitis A. Public Health Rev 13, 235-292.

Cockerill, III, F.R., \& Smith, T.F. (2002). Rapid-cycle real-time PCR: A revolution for clinical microbiology. ASM News 68, 77-83.

Craun, G.F., Nwachuku, N., Calderon, RL., \& Craun, M.F. (2002). Outbreaks in drinking-water systems, 1991-1998. J Environ Health 65, 16-25.

Crawford, S.E., Labbe, M., Cohen, J., Burroughs, M.H., Zhou, H.J., \& Estes, M.K. (1994). Characterization of virus-like particles produced by the expression of rotavirus capsid proteins in insect cells. $J$ Virol $\mathbf{6 8}, 5922-$ 5945.

Danovaro, R., Dell'anno, A., Trucco, A., Serresi, M., \& Vanucci, S. (2001). Determination of virus abundance in marine sediments. Appl Environ Microbiol 67, 1384-1387.

De Flora, S., De Renzi, G., \& Badolati, G. (1975). Detection of animal viruses in coastal seawater and sediments. Appl Environ Microbiol 30, 472-475.

Deng, M.Y., Day, S.P., \& Cliver, D.O. (1994). Detection of hepatitis A virus in environmental samples by antigencapture PCR. Appl Environ Microbiol 60, 1927-1933.

Divizia, M., Santi, A.L., \& Pana, A. (1989). Ultrafiltration: An efficient second step for hepatitis A virus and poliovirus concentration. J Virol Methods 23, 55-62.

Dore, W.J., Henshilwood, K., \& Lees, D.N. (1998). The development of management strategies for control of virological quality in oysters. Water Sci Technol 38, 29-35.

Dore, W.J., \& Lees, D.N. (1995). Behavior of Escherichia coli and male-specific bacteriophage in environmentally contaminated bivalve molluscs before and after depuration. Appl Environ Microbiol 61, 2830-2834.

Environmental Protection Agency. (1984). USEPA manual methods for virology. US Environmental Protection Agency, Research and Development, 600/4-84-013, USEPA, Cincinnati.

Farrah, S.R., Gerba, C.P., Wallis, C., \& Melnick, J.L. (1976). Concentration of viruses from large volumes of tap water using pleated membrane filters. Appl Environ Microbiol 31, 221-226.

Farrah, S.R., Goyal, S.M., Gerba, C.P., Conklin, R.H., \& Smith, E.M. (1978). Comparison between adsorption of poliovirus and rotavirus by aluminium hydroxide and activated sludge flocs. Appl Environ Microbiol 35, 360363.

Farrah, S.R., Goyal, S.M., Gerba, C.P., Wallis, C., \& Melnick, J.L. (1977). Concentration of enteroviruses from estuarine water. Appl. Environ. Microbiol 33, 1192-1196.

Farthing, M.J.G. (1989). Viruses and the Gut, Smith Kline \& French, Ltd, Welwyn Garden City. 
Fattal, B., \& Shuval H.I. (1989). Epidemiological research on the relationship between microbial quality of coastal seawater and rotavirus induced gastroenteritis among bathers on the Mediterranean Israeli beaches. Research project n' ICP-CEH-039-ISR-16(D). WHO, Athens, pp. 1-25.

Fattal, B., Vasl, R.J., Katzenelson, E., \& Shuval, H.I. (1983). Survival of bacterial indicator organisms and enteric viruses in the mediterranean coastal waters of Tel-Aviv. Water Res 17, 397-402.

Finance, C., Brigaud, M., Lucena, F., Aymard, M., Bosch, A, \& Schwartzbrod, L. (1982). Viral pollution of seawater at Barcelona. Zentralblatt Bakteriologie Mikrobiologie und Hygiene B176, 530-536.

Fuhrman, J.A., (1999). Marine viruses and their biogeochemical and ecological effects. Lancet 399, 541-548.

Fujioka, R.S., Loh, P.C., \& Lau, L.S. (1980). Survival of human enteroviruses in the Hawaiian Ocean: Environment evidence for virus inactivating microorganisms. Appl Microbiol 39, 1105-1110.

Gajardo, R., Bouchriti, N., Pintó, R.M., \& Bosch, A. (1995). Genotyping of rotaviruses isolated from sewage. Appl Environ Microbiol 61, 3460-3462.

Gajardo, R., Díez, J.M., Jofre, J., \& Bosch, A. (1991). Adsorption-elution with negatively and positively-charged glass powder for the concentration of hepatitis A virus from water. J Virol Methods 31, 345-352.

Gardner, S.N., Kuczmarski, T.A., Vitalis, E.A., \& Slezak, T.R. (2003). Limitations of TaqMan PCR for detecting divergent viral pathogens illustrated by hepatitis A, B, C, and E viruses and human immunodeficiency virus. $J$ Clin Microbiol 41, 2417-2427.

Gassilloud, B., Schwartzbrod, L., \& Gantzer, B. (2003). Presence of viral genomes in mineral water: A sufficient condition to assume infectious risk? Appl Environ Microbiol 69, 3965-3969.

Gerba, C.P., \& Goyal, S.M. (eds). (1982). Methods in Environmental Virology. Microbiology Series vol 7. Marcel Decker, New York.

Gerba, C.P., \& Schaiberger, G.E. (1975). Effect of particulates on virus survival in seawater. J Pollut Control Fed 47, 93-103.

Gerba, C.P., Smith, E.M., \& Melnick, J.L. (1977). Development of a quantitative method for detecting enteroviruses in estuarine sediments. Appl Environ Microbiol, 34, 158-163.

Gill, O.N., Cubitt, W.D., Mc. Wiggan, D.A., Watney, B.M., \& Bartlett, C.L.R. (1983). Epidemic of gastroenteritis caused by oysters contaminated with small round structured viruses. Br Med J 287, 1532-1534.

Gironés, R., Jofre, J., \& Bosch, A. (1989). Natural inactivation of enteric viruses in seawater. J Environ Qual 18, 34-39.

Girones, R., Jofre, J., \& Bosch, A. (1990). Isolation of marine bacteria with antiviral properties. Can J Microbiol 35, 1015-1021.

Glass, R.I., Noel, J., Mitchell, D.K., Herrmann, J.E., Blacklow, N.R., Pickering, L.K., Dennehy, P., Ruiz-Palacios, G., de Guerrero, M.L., \& Monroe, S.S. (1996). The changing epidemiology of astrovirus-associated gastroenteritis: A review. Arch Virol (Suppl), 12, 287-300.

Goh, K.T., Chan, L., Ding, J.L., \& Oon C.J. (1984). An epidemic of cockles associated hepatitis A in Singapore. WHO Bull 62, 893-897.

Goyal, S.M. (1984). Viral pollution of the marine environment. Crit Rev Environ Control, 14, 1-32.

Goyal, S.M., \& Gerba, C.P. (1983). Viradel method for detection of rotavirus from seawater. J Virol Methods 7, 279-285.

Goyal, S.M., Gerba, C.P. , \& Melnick, J.L. (1979). Human enteroviruses in oysters and their overlaying waters. Appl Environ Microbiol 37, 572-581.

Graff, J., Ticehurst, J., \& Flehmig, B. (1993). Detection of hepatitis A virus in sewage sludge by antigen capture polymerase chain reaction. Appl Environ Microbiol 59, 3165-3170.

Green, J., Henshilwood, K., Gallimore, C.I., Brown, D.W.G., \& Lees, D.N. (1998). A nested reverse transcriptase PCR assay for detection of small round structured viruses in environmentally contaminated molluscan shellfish. Appl Environ Microbiol 64, 858-863.

Gunderson, K., Brandberg, A., Magnusson, S., \& Lycke, E. (1968). Characterization of a marine bacterium associated with virus inactivating capacity. Acta Pathologica et Microbiologica Scandinava, 71, 281-286.

Halliday, M.L., Kang, L.-Y,. Zhou, T.-Z., Hu, M.-D., Pan, Q.-C., Fu, T.-Y., Huang, Y.S., \& Hu, S.L. (1991). An epidemic of hepatitis A attributable to the ingestion of raw clams in Shanghai, China. Int J Infect Dis 164, 852-859.

Havelaar, A.H. (1993). Bacteriophages as models of human enteric viruses in the environment. ASM News 59, 614619.

Hejkal, T.W., \& Gerba, C.P. (1981). Uptake and survival of enteric viruses in the blue crab, Gallinetes sapidus. Appl Environ Microbiol 41, 207-211. 
Hejkal, T.W., Smith, E.M., \& Gerba, C.P. (1984). Seasonal occurrence of rotavirus in sewage. Appl Environ Microbiol 47, 588-590.

Heller, D., Gill, O.N., Raynham, E., Kirkland, T., Zadick, P.M., \& Stanwell-Smith, R. (1986). An outbreak of gastrointestinal illness associated with consumption of raw depurated oysters. Br Med J 292, 1726-1727.

Henshilwood, K., Green, J., \& Lees, D.N. (1998). Monitoring the marine environment for small round structured viruses (SRSVS): A new approach to combating the transmission of these viruses by molluscan shellfish. Water Sci Technol 38, 51-56.

Hugues, B., Cini, A., Plissier, M. \& Lefebre, J.R. (1980). Recherche des virus dans le milieu marin à partir d'échantillons de volumes différents. Eau Ouetec 13, 199-203.

IAWPRC Study Group on Health Related Water Microbiology (A.H. Havelaar, ed.). (1991). Bacteriophages as model viruses in water quality control. Water Res 25, 529-545.

Jaykus, L.A., De Leon, R., \& Sobsey, M.D. (1996). A virion concentration method for detection of human enteric viruses in oysters by PCR and oligoprobe hybridization. Appl Environ Microbiol 62, 2074-2080.

Jaykus, L.A., Hemard, M.T., \& Sobsey, M.D. (1994). Human enteric pathogenic viruses. In C.R. Hackney and M.D. Pierson (eds), Environ Indicators and Shellfish Safety. Chapman and Hall, New York, pp. 92-153.

Jean, J., Blais, B., Darveau, A., \& Fliss, I. (2001). Detection of hepatitis A virus by the nucleic acid sequence-based amplification technique and comparison with reverse transcription-PCR. Appl Environ Microbiol 67, 5593-5600.

Jofre, J., Blasi, M., Bosch, A., \& Lucena, F. (1989). Occurrence of bacteriophages infecting bacteroides fragilis and other viruses in polluted marine sediments. Water Sci Technol, 21, 15-19.

Jofre, J., Lucena, F., Gajardo, R., \& Bosch, A. (1993). Detection of human enteric viruses in mussels (Mytilus edulis). In S.R. Farrah, C.P. Gerba, \& R. Walter (eds), Contamination of the Environment by Viruses and Methods of Control. Agriculture University, Vienna, pp. 105-110.

Jothikumar, N., Khanna, P., Paulmurugan, R., Kamatchiammal, S., \& Padmanabhan, P. (1995). A simple device for the concentration and detection of enterovirus, hepatitis $\mathrm{E}$ virus and rotavirus from water samples by reverse transcription-polymerase chain reaction. J Virol Methods 55, 401-415.

Kageyama, T., Kojima, S., Shinohara, M., Uchida, K., Fukushi, S., Hoshino, F.B., Takeda, N., \& Katayama, K. (2003). Broadly reactive and highly sensitive assay for Norwalk-like viruses based on real-time quantitative reverse transcription-PCR. J Clin Microbiol 41, 1548-1557.

Katzenelson, E., Fattal, B., \& Hostovesky, T. (1976). Organic flocculation: An efficient second-step concentration method for the detection of viruses in tap water. Appl Environ Microbiol 32, 638-639.

Kingsley, D.H., Meade, G.K., \& Richards, G.P. (2002). Detection of both hepatitis A virus and Norwalk-like virus in imported clams associated with food-borne illness. Appl Environ Microbiol 68, 3914-3918.

Kitamoto, N.K., Ramig, R.F., Matson, D.O., \& Estes, M.K. (1991). Comparative growth of different rotavirus strains in differentiated cells (MA104, HepG2 and CaCo-2). Virology 184, 729-737.

Kohn, M.A., Farley, T.A, Ando, T., Curtis, M., Wilson, S.A., Jin, Q., Monroe, S.S., Baron, R.C., McFarland, L.M., \& Glass, R.I. (1995). An outbreak of Norwalk virus gastroenteritis associated with eating raw oysters. Implications for maintaining safe oyster beds $J$ Am Med Assoc 273, 466-471.

Koopman, J.S., Eckert, E.A., Greenberg, H.B., Strohm, B.C., Isaacson, R.E. \& Monto, A.S. (1982). Norwalk virus enteric illness acquired by swimming exposure. Am J Epidemiol 115, 173-177.

Ksiazek, T.G., Erdman, D. Goldsmith, C.S., Zaki, S.R., Peret, T., Emery, S., Tong, S., Urbani, C., Comer, J.A., Lim, W. et al. (2003). A novel coronavirus associated with severe acute respiratory syndrome. $N$ Engl J Med 348, 1953-1966.

La Belle, R.L., Gerba, C.P., Goyal, S.M., Melnick, J.L., Lech, I., \& Bogdan, G.F. (1980). Relationships between environmental factors, bacterial indicators and the occurrence of enteric viruses in estuarine sediments. Appl Environ Microbiol 39, 588-596.

Lawton, J.A., Zeng, C.Q., Mukherjee, S.K., Cohen, J., Estes, M.K., \& Prasad, B.V. (1997). Three-dimensional structural analysis of recombinant rotavirus-like particles with intact and amino-terminal-deleted VP2: Implications for the architecture of the VP2 capsid layer. J Virol 71, 7353-7360.

Lees, D.N. (2000). Viruses and bivalve shellfish. Int J Food Microbiol 59, 81-116.

Lees, D.N., Henshilwood, K., \& Dore, W.J. (1994). Development of a method for detection of enteroviruses in shellfish by PCR with poliovirus as a model. Appl Environ Microbiol 60, 2999-3005.

Le Guyader, F., Dubois, E., Menard, D., \& Pommepuy, M. (1994). Detection of hepatitis A virus, rotavirus, and enterovirus in naturally contaminated shellfish and sediment by reverse transcription-seminested PCR. Appl Environ Microbiol 60, 3665-3671.

Le Guyader, F., Haugarreau, L., Miossec, L. Dubois, E., \& Pommepuy, M. (2000). Three-year study to assess human enteric viruses in shellfish. Appl Environ Microbiol 66, 3241-3248. 
Le Guyader, F., Neill, F.H., Estes, M.K., Monroe, S.S., Ando, T., \& Atmar, R.L. (1996). Detection and analysis of a SRSV strain in oysters implicated in an outbreak. Appl Environ Microbiol 62, 4268-4272.

Lewis, G.D., \& Metcalf, T.G. (1988). Polyethylene glycol precipitation for recovery of pathogenic viruses, including hepatitis A virus and human rotavirus, from oysters, water and sediment samples. Appl Environ Microbiol 54, 1983-1988.

Linco, S.J., \& Grohmann, G.S. (1980). The Darwin outbreak of oyster associated viral gastroenteritis. Med J Aust 1, 211-213.

Loisy, F., Le Cann, P., Pommepuy, M., \& Le Guyader, F. (2000). An improved method for the detection of Norwalk-like caliciviruses in environmental samples. Lett Appl Microbiol 31, 411-415.

López-Sabater, E.I., Deng, M.Y., \& Cliver, D.O. (1997). Magnetic immunoseparation PCR assay (MIPA) for detection of hepatitis A virus (HAV) in American oyster (Crassostrea virginica). Lett Appl Microbiol 24, 101-104.

Lopman, B.A., Reacher, M.H. Van Duijnhoven, Y. Hanon, F.X. Brown, D., \& Koopmans, M. (2003). Viral gastroenteritis outbreaks in Europe, 1995-2000. Emerg Infect Dis 9, 90-96.

Lucena, F., Bosch, A., Jofre, J., \& Schwartzbrod, L. (1985). Identification of viruses isolated from sewage, riverwater and coastal seawater in Barcelona. Water Res 19, 1237-1239.

Lucena, F., Schwartzbrod, L., \& Bosch, A. (1986). The effect of a mass poliomyelitis vaccination program on the occurrence of enterovirus in seawater. Zentralblatt Bakteriologie Mikrobiologie und Hygiene, B183, 67-69.

Ma, J.F., Straub, T.M., Pepper, I.L., \& Gerba, C.P. (1994). Cell culture and PCR determination of poliovirus inactivation by disinfectants. Appl Environ Microbiol 60, 4203-4206.

Mackowiak, P.A., Caraway, C.T., \& Portnoy, B.L. (1976). Oyster associated hepatitis: Lessons from the Louisiana experience. Am J Epidemiol 103, 181-191.

Matossian, A.M., \& Garabedian, G.A. (1967). Virucidal action of seawater. Am J Epidemiol 85, 1-8.

McDonnell, S., Kirkland, K.B., Hlady, W.G., Aristeguieta, C., Hopkins, R.S., Monroe, S.S., \& Glass, R.I. (1997). Failure of cooking to prevent shellfish-associated viral gastroenteritis. Arch Intern Med 157, 111-116.

Mehnert, D.U., Stewien, K.E., Hársi, C.M., Queiroz, A.P.S., Candeias, J.M.G. \& Candeias, J.A.N. (1997). Detection of rotavirus in sewage and creek water: Efficiency of the concentration method. Memórias do Instituto Oswaldo Cruz, 92, 97-100.

Mele, A., Rastelli, M.G., Gill, O.N., DiBisceglie, D., Rosmini, F., Pardelli, G., Valtriani, C., \& Patriarchi, P. (1989). Recurrent epidemic hepatitis A associated with the consumption of raw shellfish, probably controlled through public health measures. Am J Epidemiol 130, 540-546.

Melnick, J.L. (1957). A water-borne urban epidemics of hepatitis. In G.A. LoGrippo, F.W. Hartman, J.G. Mateer, and J. Barron (eds), Hepatitis Frontiers. Little Brown, Boston, pp. 211-225.

Mendez, I., Hermann, L., Hazelton, P., \& Coombs, K. (2000). A comparative analysis of Freon substitutes in the purification of reovirus and calicivirus. $J$ Virol Methods 90, 59-67.

Metcalf, T.G., Mullin, B., Eckerson, D., Moulton, E., \& Larkin, E.P. (1979). Bioaccumulation and depuration of enteroviruses by the soft shelled clam, Mya arenaria. Appl Environ Microbiol 38, 275-282.

Miossec, L., Le Guyader, F., Pelletier, D., Haugarreau, L., Caprais, M.-P., \& Pommepuy, M. (2001). Validity of Escherichia coli, enterovirus and F-specific RNA bacteriophages as indicators of viral shellfish contamination. J Shellfish Res 20, 1223-1227.

Moore, A.C., Herwaldt, B.L., Craun, G.F., Calderon, R.L., Highsmith, A.K. \& Juranek, D.D. (1994). Waterborne disease in the United States, 1991 and 1992. J Am Water Works Assoc 86, 87-99.

Morris, R., \& Waite, W.M. (1980). Evaluation of procedures for recovery of viruses from water. II. Detection systems. Water Res 14, 795-798.

Morse, D.L., Guzewich, J.J., Hanrahan, J.P., Stricof, R., Shayegani, M., Deibel, R., Grabau, J.C., Nowak, N.A., Herrmann, J.E., Cukor, G., \& Blacklow, N.R., (1986). Widespread outbreaks of clam- and oyster-associated gastroenteritis: Role of Norwalk virus. N Engl J Med 314, 678-681.

Murphy, A.M., Grohmann, G.S., Christopher, R.J., Lopez, W.A., Davey, G.R., \& Millsom, R.H. (1979). An Australiawide outbreak of gastroenteritis from oysters caused by Norwalk virus. Med J Aust 2, 329-333.

Murrin, K., \& Slade, J. (1997). Rapid detection of viable enteroviruses in water by tissue culture and semi-nested polymerase chain reaction. Water Sci Technol 35, 429-432.

Oh, D.-Y., Gaedicke, G., \& Schreir, J.M. (2003). Viral agents of acute gastroenteritis in German children: Prevalence and molecular diversity. J Med Virol 71, 82-93.

O’Mahony, M., Gooch, C.D., Smyth, D.A., Thrussell, A.J., Bartlett, C.L.R., \& Noah, N.D. (1983). Epidemic hepatitis A from cockles. Lancet, i, (8323) 518-520.

Otwell, W.S., Rodrick, G.E., \& Martin, R.E (eds). (1991). Molluscan Shellfish Depuration. CRC Press, Boca Raton, FL. 
Parashar, U.D., Holman, R.C. Clarke, M.J. Bresee, J.S., \& Glass R.I. (1998). Hospitalizations associated with rotavirus diarrhea in the United States, 1993 through 1995: Surveillance based on the new ICD-9-CM rotavirus-specific diagnostic code. J Infect Dis 177, 13-17.

Pintó, R.M., Abad, F.X. Gajardo, R., \& Bosch, A. (1996). Detection of infectious astroviruses in water. Appl Environ Microbiol 62, 1811-1813.

Pintó, R.M., Gajardo, R., Abad, F.X. \& Bosch, A. (1995). Detection of fastidious infectious enteric viruses in water. Environ Sci Technol 29, 2636-2638.

Pintó, R.M., Villena, C., Le Guyader, F., Guix, S., Caballero, S., Pommepuy, M., \& Bosch, A. (2001). Astrovirus detection in wastewater samples. Water Sci Technol 12, 73-76.

Power, U.F., \& Collins, J.K. (1989). Differential depuration of poliovirus Escherichia-coli and a coliphage by the common mussel Mytilus-edulis. Appl Environ Microbiol 55, 1386-1390.

Power, U.F., \& Collins, J.K. (1990). Elimination of coliphages and Escherichia coli from mussels during depuration under varying conditions of temperature salinity and food availability. J Food Prot 53, 208-212, 226.

Rao, V.C., \& Melnick, J.L. (1986). Environmental Virology. In J.A. Cole, C.J. Knowles, and D. Schlessinger (eds), Aspects of Microbiology. American Society for Microbiology, Washington, DC, vol. 13.

Rao, V.C., Metcalf, T.G., \& Melnick, J.L. (1986a). Development of a. method for concentration of rotavirus and its application to recovery of rotaviruses from estuarine waters. Appl Environ Microbiol 52, 484-488.

Rao, V.C., Metcalf, T.G., \& Melnick, J.L. (1986b). Human viruses in sediments, sludges, and soils. Bull World Health Organ 64, 1-13.

Rao, V.C., Seidel, K.N., Goyal, S.M., Metcalf, T.C., \& Melnick, J.L. (1984). Isolation of enteroviruses from water, suspended solids and sediments from Galveston bay; survival of poliovirus and rotavirus adsorbed to sediments. Appl Environ Microbiol 48, 404-409.

Redman, J.A., Grant, S.B. Olson, T.M. Hardy, M.E., \& Estes, M.K. (1997). Filtration of recombinant Norwalk virus particles and bacteriophage MS2 in quartz sand: Importance of electrostatic interactions. Environ Sci Technol 31, 3378-3383.

Reid, T.M.S., \& Robinson, H.G. (1987). Frozen raspberries and hepatitis A. Epidemiol Infect 98, 109-112.

Reyes, G.R. (1993). Hepatitis E virus (HEV): molecular biology and emerging epidemiology. Prog Liver Dis 11, 203-213.

Reynolds, K.A., Gerba, C.P., \& Pepper, I.L. (1996). Detection of infectious enteroviruses by an integrated cell culturePCR procedure. Appl Environ Microbiol 62, 1424-1427.

Richards, G.P. (1985). Outbreaks of shellfish-associated enteric illness in the United-States: Requisite for development of viral guidelines. J Food Prot 48, 815-823.

Richards, G.P. (1988). Microbial purification of shellfish a review of depuration and relaying. J Food Prot 51, 218-251.

Romalde, J.L., Area, E., Sánchez, G., Ribao, C., Torrado, I., Abad, F.X., Pintó, R.M., Barja, J.L., \& Bosch, A. (2002). Prevalence of enterovirus and hepatitis A virus in bivalve mollusks from Galicia (NW Spain): Inadequacy of the EU standards of microbiological quality. Int J Food Microbiol 74, 119-130.

Romalde, J.L., Estes, M.K., Szucs, G., Atmar, R.L., Woodley C.M., \& Metcalf, T.G. (1994). In situ detection of hepatitis A virus in cell cultures and shellfish tissues. Appl Environ Microbiol 60, 1921-1926.

Sánchez, G., Pintó, R.M., Vanaclocha, H. \& Bosch, A. (2002). Molecular characterization of hepatitis A virus isolates from a transcontinental shellfishborne outbreak. J Clin Microbiol 40, 4148-4155.

Santa Monica Bay Restoration Project. (1996). An Epidemiological Study of Possible Adverse Health Effects of Swimming in Santa Monica Bay. Santa Monica Bay Restoration Project, Monterey Park, CA, p. 211.

Sarrette, B.A., Danglot, C.D., \& Vilagines, R. (1977). A new and simple method for recuperation of enterovirus from water. Water Res 11, 355-358.

Schaiberger, G.E., Edmond, T.D., \& Gerba, C.P. (1982). Distribution of enteroviruses in sediments contiguous with a deep marine sewage outfall. Water Res 16, 1425-1428.

Schlauder, G.G., \& Mushahwar, I.K. (2001). Genetic heterogeneity of hepatitis E virus. J Med Virol 65, 282-292.

Schwab, K.J., De Leon, R., \& Sobsey, M.D. (1995). Concentration and purification of beef extract mock eluates from water samples for the detection of enteroviruses, hepatitis A virus, and Norwalk virus by reverse transcriptionPCR. Appl Environ Microbiol 61, 531-537.

Schwab, K.J., Neill, F.H., Fankhauser, R.L., Daniels, N.A., Monroe, S.S., Bergmire-Sweat, D.A., Estes, M.K., \& Atmar, R.L. (2000). Development of methods to detect "Norwalk-like viruses" (NLVs) and hepatitis A virus in delicatessen foods: Application to a food-borne NLV outbreak. Appl Environ Microbiol 66, 213-218.

Schwartzbrod, L., \& Lucena, F. (1978). Concentration des enterovirus dans les eaux par adsorption sur poudre de verre: Proposition d'un apareillage simplifié. Microbia, 4, 55-68. 
Seyfried, D.L., Tobin, R.S., Brown, W.E. \& Ness, P.F. (1985). A prospective study of swimming-related illness. II. Morbidity and the microbiological quality of water. Am J Public Health 75, 1071-1075.

Shieh, C.Y.-S. Calci, K.R., \& Baric, R.S. (1999). A Method To Detect Low Levels of Enteric Viruses in Contaminated Oysters. Appl Environ Microbiol 65, 4709-4714.

Shields, P.A., \& Farrah, S.R. (1986). Concentration of viruses in beef extract by flocculation with ammonium sulphate. Appl Environ Microbiol 51, 211-213.

Smith, E.M., \& Gerba, C.P. (1982). Development of a method for detection of human rotavirus in water and sewage. Appl Environ Microbiol 43, 1440-1450.

Sobsey, M.D., Carrick, R.J., \& Jensen, H.R. (1978). Improved methods for detecting enteric viruses in oysters. Appl Environ Microbiol 36, 121-128.

Sobsey, M.D. \& Glass, J.S. (1984). Influence of water quality on enteric virus concentration by microporous filter methods. Appl Environ Microbiol 47, 956-960.

Sobsey, M.D., \& Hickey, A.R. (1985). Effect of humic and fulvic acid on poliovirus concentration from water by microporous filtration. Appl Environ Microbiol 49, 259-264.

Sobsey, M.D., \& Jones, B.L. (1979). Concentration of poliovirus from tap water using positively charged microporous filters. Appl Environ Microbiol 37, 588-595.

Sobsey, M.D., Shields, P.A., Hauchman, F.S., Davis, A.L., Rullman, V.A. \& Bosch, A. (1988). Survival and persistence of hepatitis A virus in environmental samples. In A.J. Zuckerman (ed), Viral Hepatitis And Liver Disease Alan R. Liss, New York, pp. 121-124.

Sockett, P.N., Cowden, J.M., LeBaigue, S., Ross, D., Adak, G., \& Evans, H. (1993). Foodborne disease surveillance in England and Wales: 1989-1991. Commun Dis Rep 3, 159-174.

Steinman, J. (1981). Detection of rotavirus in sewage. Appl Environ Microbiol 41, 1043-1045.

Tartera, C., \& Jofre, J. (1987). Bacteriophages active against Bacteroides fragilis in sewage-polluted waters. Appl Environ Microbiol 53, 1632-1637.

Toranzo, A.E., Barja, J.L., \& Hetrick, F.M. (1983). Mechanism of poliovirus inactivation by cell-free filtrates of marine bacteria. Can J Microbiol 29, 1481-1486.

Tsai, Y.L., Sobsey, M.D., Sangermano, L.R., \& Palmer, C.J. (1993). Simple method of concentrating enteroviruses and hepatitis A virus from sewage and ocean water for rapid detection by reverse transcriptase-polymerase chain reaction. Appl Environ Microbiol 59, 3488-3491.

Tsai, Y.-L., Tran, B., \& Palmer, C.J. (1995). Analysis of viral RNA persistence in seawater by reverse transcriptasePCR. Appl Environ Microbiol 61, 363-366.

Tsang, T. (2003). Environmental issues. Presented at WHO Global Conference on Severe Acute Respiratory Syndrome (SARS), Kuala Lumpur, Malaysia, June 17-18 2003.

Van Donsel, D.J., \& Geldreich, E.E. (1971). Relationships of Salmonellae to fecal coliforms in bottom sediments. Water Res 5, 1079-1087.

Vaughn, J.M., Landry, E.F., Thomas, M.Z., Vicale, T.J., \& Penello, W.F. (1979). Survey of human enterovirus occurrence in fresh and marine surface waters on Long-Island. Appl Environ Microbiol 38, 290-296.

Vilaginès, P., Sarrette, B., Champsaur, H., Hugues, B., Dubrou, S., Joret, J.-C., Laveran, H., Lesne, J., Paquin, J.L., Delattre J.M., et al. (1997). Round robin investigation of glass wool method for poliovirus recovery from drinking water and sea water. Water Sci Technol 35, 445-449.

Villena, C., Morsy El-Senousy, W., Abad, F.X., Pintó, R.M., \& Bosch, A. (2003). Group A rotavirus in sewage samples from Barcelona and Cairo: Emergence of unusual genotypes. Appl Environ Microbiol 69, 3919-3923.

Wait, D.A., \& Sobsey, M.D. (1983). Method for recovery of enteric viruses from estuarine sediments with caotropic agents. Appl Environ Microbiol 46, 379-385.

Wallis, C., \& Melnick, J.L. (1967). Concentration of viruses on aluminium and calcium salts. Am J Epidemiol 85, 459.

Williams, R.A., \& Zorn, D.J. (1997). Hazard analysis and critical control point systems applied to public health risks: The example of seafood. Revue Scientifique et Technique, 16, 349-358.

Yates, S., Penning, M., Goudsmit, J., Frantzen, I., Van der Weijer, B., Van Strijp, D., \& Van Gemen, B. (2001). Quantitative detection of hepatitis B virus DNA by real-time nucleic acid sequence-based amplification with molecular beacon detection. J Clin Microbiol 39, 3656-3665. 